\title{
A Critical Examination of Representation and Culture in Four English Language Textbooks
}

\author{
Amanda D. Hilliard \\ Arizona State University, Arizona, USA
}

\begin{abstract}
In light of the importance of intercultural communicative competence in today's global society, this study examined the topics, images, audio material, hidden ideologies, perspectives, cultural information, and cultural activities in four English language textbooks from a pedagogical perspective. Overall, the four textbooks were shown to include a limited scope of topics, under-represent a variety of minority groups in the culture represented, contain a limited range of accents in their audio material, generally lack in-depth cultural information, and contain a paucity of cultural activities targeting the development of students' intercultural communicative skills. The study concludes that textbook publishers need to improve the cultural representation of minorities, variety of accents included in audio material, depth of cultural information, and effectiveness of cultural activities in their English language textbooks. Furthermore, teachers must be aware of hidden stereotypes, values, and ideologies to overcome the pedagogical limitations of the cultural information and activities of language textbooks.
\end{abstract}

Cultural values are expressed in the different ways languages categorize items, express politeness, and maintain hierarchies, as well as through different vocabulary items, idioms, proverbs, and other sayings (Decapua \& Wintergerst, 2004). Because culture is such an integral part of language, it would be difficult, if not impossible, to teach a language without teaching at least some aspects of its culture.

A number of researchers and teachers have advocated making the development of students' intercultural communicative competence one goal of the language classroom and thus advocate teaching culture in the language classroom (Byram, 2008; Sercu, 2010). Intercultural communicative competence can be defined as the ability "to interact with people from another country and culture in a foreign language" (Byram, 1997, p. 71). Developing intercultural competence goes beyond the mechanics of language and requires students to learn about cultural knowledge and practices in order to improve the learning of interculture, improve intercultural communicating skills, and adopt an interculturalist identity (Sercu, 2010).

In addition, recent developments in critical pedagogy have led some researchers to suggest that helping students develop into culturally aware, sensitive international citizens should be one goal of language education, necessitating a cultural component and activities to raise students' intercultural sensitivity within the language classroom (see Byram, 2008). This focus on

Language Education in Asia, 2014, 5(2), 238-252. http://dx.doi.org/10.5746/LEiA/14/V5/I2/A06/Hilliard 
developing students' intercultural communicative competence and on helping students develop into international citizens represents a shift in the role of language education. Rather than focusing solely on teaching the mechanics of language, it is now being suggested that language teaching should incorporate more activities for cultural awareness and individual development (Gray, 2010).

\section{Previous Research}

Since textbooks both implicitly and explicitly present students with representations of other cultures and values, it is critical that textbooks be evaluated from a pedagogical standpoint. Previous studies have generally focused on representations of gender, race, nationality, and culture in both curricular and language textbooks to reveal hidden ideologies, stereotypes, and assumptions within the textbooks themselves (see Byram \& Esarte-Sarries, 1991; Eriksson \& Aronsson, 2005; Gray, 2002, 2010; Heinrich, 2005; Lee \& Collins, 2010; Shin, Eslami, \& Chen, 2011; Sleeter \& Grant, 1991). In general, these studies have revealed a trend in recent years towards more equal representation of women and increasingly multicultural content. However, they have also revealed hidden ideologies of individualism and materialism as well as a tendency to present a superficial and overly positive view of the target culture.

While earlier language books were shown to present women unfairly in terms of proportional representation, stereotypes of women's roles, and other gender stereotypes, recently, textbook publishers appear to be making an effort to eradicate this problem (Gray, 2002). Gray's 2010 survey of language textbooks dating from 1984 to 2003 upheld this trend towards the "feminizing of content," as the earlier textbooks tended to be more sexist and later textbooks tended to represent women more fairly (p. 109). Even so, Sleeter and Grant (1991) suggested that modern curricular textbooks largely tend to avoid discussing issues of gender by simply eliminating sexist language, and a more recent study by Lee and Collins (2010) suggested that there may be differences in the representation of women in textbooks used in different countries.

Other studies have suggested that minority groups are generally under-represented, stereotyped, or otherwise portrayed inaccurately in language and curricular textbooks (Gray, 2002; Sleeter \& Grant, 1991; Taylor-Mendes, 2009). Sleeter and Grant conclude that "the curriculum focuses on the White male and downplays or simply ignores the accomplishments and concerns of Americans who are of color, female, poor, and/or disabled" (1991, p. 98). Furthermore, a 2009 study by Taylor-Mendes on images in English language textbooks suggested that pictures in textbooks condone racial biases, solidify entrenched racial stereotypes in the culture portrayed, and "reinforce a made-in-Hollywood version of culture that does not exist" (p. 77).

Finally, a number of studies have suggested that general cultural representations in language textbooks may be unrealistic, superficial, or idealistic (Byram \& Esarte-Sarries, 1991; Gray, 2002, 2010; Gulliver, 2010; Heinrich, 2005; Kubota, 2002; Shin et al., 2011). For example, in a 1991 study of French language coursebooks, Byram and Esarte-Sarries found that representations of French people and culture were generally urban, positive, and unrealistic. Similar studies by Kubota (2002) and Heinrich (2005) both found that Japanese language textbooks tend to present an idealized, positive version of Japanese culture and language, which may hinder language learning by "alienating learners from discovering how to function effectively in real social contexts" (Kubota, 2002, p. 26). Moreover, a number of researchers have expressed concerns about hidden cultural and political ideologies represented in English language textbooks, such as the cultural values of individualism, egalitarianism, and materialism (Canagarajah, 1999; Dunnet, Dubin, \& Lezberg, 1986; Gray, 2010; Pennycook, 1994; Phillipson, 1992). 


\section{English as an International Language}

Recently, what it means to teach English as an International Language (EIL) has become a widely developed issue in the ELT community. Recognizing that there are more non-native speakers than native speakers, that English is spoken in a wide variety of contexts throughout the world, and that a number of varieties of English are used globally influences conceptualizations of teachers' roles, linguistic content to be taught, and expectations for students to be communicatively competent (Naji Meidani \& Pishghadam, 2013; Sharifian, 2013; Shin et al., 2011; Yuen, 2011). Researchers examining English language textbooks from an EIL perspective have found them to be limited in variety and depth of cultural content (Shin et al., 2011; Yuen, 2011) and misleading for students (Forman, 2014).

First, Yuen claims that if English is to be used for intercultural communication, then teaching materials should include information from a variety of cultures, not just the cultures of Englishspeaking countries (2011, p. 253). Examining two English language textbooks used in Hong Kong, Yuen (2011) found that the cultures of English-speaking countries were over-represented, while Asian or African cultures were under-represented. In addition, products, or Big-C culture were depicted more frequently than perspectives, or little-c culture. Textbook analysis by Shin, Eslami, and Chen (2011) showed similar results, with a disproportionate amount of inner circle cultural information included in the texts and cultural information remaining at the knowledgeoriented level rather than engaging learners in deep reflection.

Researching the way local teachers use English language textbooks in rural Thailand, Forman (2014) found that teachers adhere to the cultural information presented in the texts, even if the information is irrelevant, confusing, or misleading for students. As Forman notes, for these teachers "the textbook is the curriculum," with an authority "beyond criticism," making the cultural information included in textbooks particularly influential in EFL contexts (2014, p. 7273). Like Yuen (2011), Forman (2014) suggests that the content of textbook materials should include a variety of cultural material, both local and global.

With the rise of Communicative Language Teaching and the need for students to use English to communicate in international and intercultural situations, researchers now emphasize the importance of developing students' intercultural competence (Alptekin, 2002; Schnitzer 1995) and metacultural competence (Sharifian, 2013). This means that culture should play an important role in the foreign language curriculum and that cultural materials for language teaching must be re-examined with the goal of developing intercultural communicative competence in mind.

\section{Methodology}

The purpose of this study was to uncover hidden ideologies and values within the texts and to evaluate the general effectiveness of cultural information and activities included in the textbooks from a pedagogical perspective. Overall, this study aimed to address three main questions:

1. What kinds of cultural materials are included in English language textbooks today? How are different groups and cultures represented in the textbooks?

2. Are there any hidden values or assumptions in the cultural material included in English language textbooks? 
3. What are the pedagogical implications of the cultural information and activities included in the textbooks? Will this information and these activities help students develop their communicative cultural competence?

To address these questions, four series of popular English language textbooks used globally were selected, a form for analysis was created based on previous research, and the analysis was divided into three separate readings.

\section{The Textbooks}

This study focused on textbooks widely used around the world to teach general English language skills for adults and avoided books published for specific contexts, specific groups, or specific purposes. An intermediate level textbook was chosen from four popular series produced by major ELT textbook publishers between 2003 and 2011. For the purpose of this paper, the textbooks will be referred to as Textbook A, Textbook B, Textbook C, and Textbook D.

\section{The Analysis}

A framework for analysis (see Appendix) was developed for this study after examining frameworks from Risager (1991), Sercu (in Gray, 2010, p. 40), and Gray (2010). The framework used in this study combines the three frameworks to include an emphasis on culture on multiple levels, a concern for the pedagogical implications of the cultural material, and the analysis of accents and varieties of English in the audio material. The framework allows for both quantitative analysis of pictures, topics, and audio material in Sections I and II, and more qualitative analysis of cultural values, perspective, and pedagogical implications in Sections III and IV to provide a holistic overview of each course book.

\section{First Examination}

The first reading included Sections I and II of the analysis form (see Appendix) and aimed at achieving a general idea of the overall structure of the textbooks, their main topics, and the types of texts and varieties of accents they contained. During this reading, formal counts were taken of the topics included in each unit of the book, the gender and nationality or ethnicity of the people in the textbook images, and the accent and variety of English used in the audio material of each textbook.

\section{Second Examination}

The second reading included Section III of the analysis framework and focused on examining the cultural content of each textbook. Cultural content was examined on four levels: the micro level, the macro level, international and intercultural issues, and the point of view of the authors.

\section{Third Examination}

Last, each textbook was examined a third time for pedagogical implications using Sections IV and $V$ of the framework. This included examining the type, educational potential, and objectives of each task in the textbook, determining whether the texts and tasks address students' knowledge, attitudes, and cultural frame of reference, and commenting on the effectiveness of each textbook in developing students' communicative cultural competence. 


\section{Data and Findings}

Overall, the textbooks were shown to include a limited range of topics, images, and accents and to under-represent a wide variety of minorities, nationalities, and cultures. While all the textbooks include some explicit cultural material, activities, and discussion which may help develop students' cultural knowledge and awareness, there are few, if any, activities included in the textbooks which would further develop students' intercultural communication skills.

\section{Topics}

In general, a limited range of topics are included in the four ELT textbooks surveyed in this study, which may be due to what Gray (2002) refers to as "inappropriacy," or the tendency of textbook publishers to avoid certain topics based on customers' cultural sensitivities. By focusing only on positive or neutral aspects of the target culture and excluding negative or sensitive information, the target culture may be misrepresented.

\section{Representations of Ethnicity in Textbook Images}

The ethnicity for people within textbook images was determined by examining the clothing, environment, surrounding objects, and person's appearance within the picture, as well as by examining information found in accompanying texts. Any images in which the ethnicity was not clear from the image or surrounding texts were counted as Not Determined (ND). As shown in Figure 1 below, the percentage of Caucasians in the pictures in the textbooks varies from 58.6 to 85 percent, making them the most prominent and heavily represented group in all four textbooks. The percentages of pictures of people of Asian, Spanish, or African descent vary by textbook from as low as 2.4 percent to as high as 18.5 percent. The "Other" category includes people of Native American or Middle Eastern descent. In all the textbooks, the "Other" category has the lowest percentage, meaning that Native Americans, Middle Easterners, and other minority groups in the culture represented appear in images even less frequently than people of Asian, Spanish, or African descent.

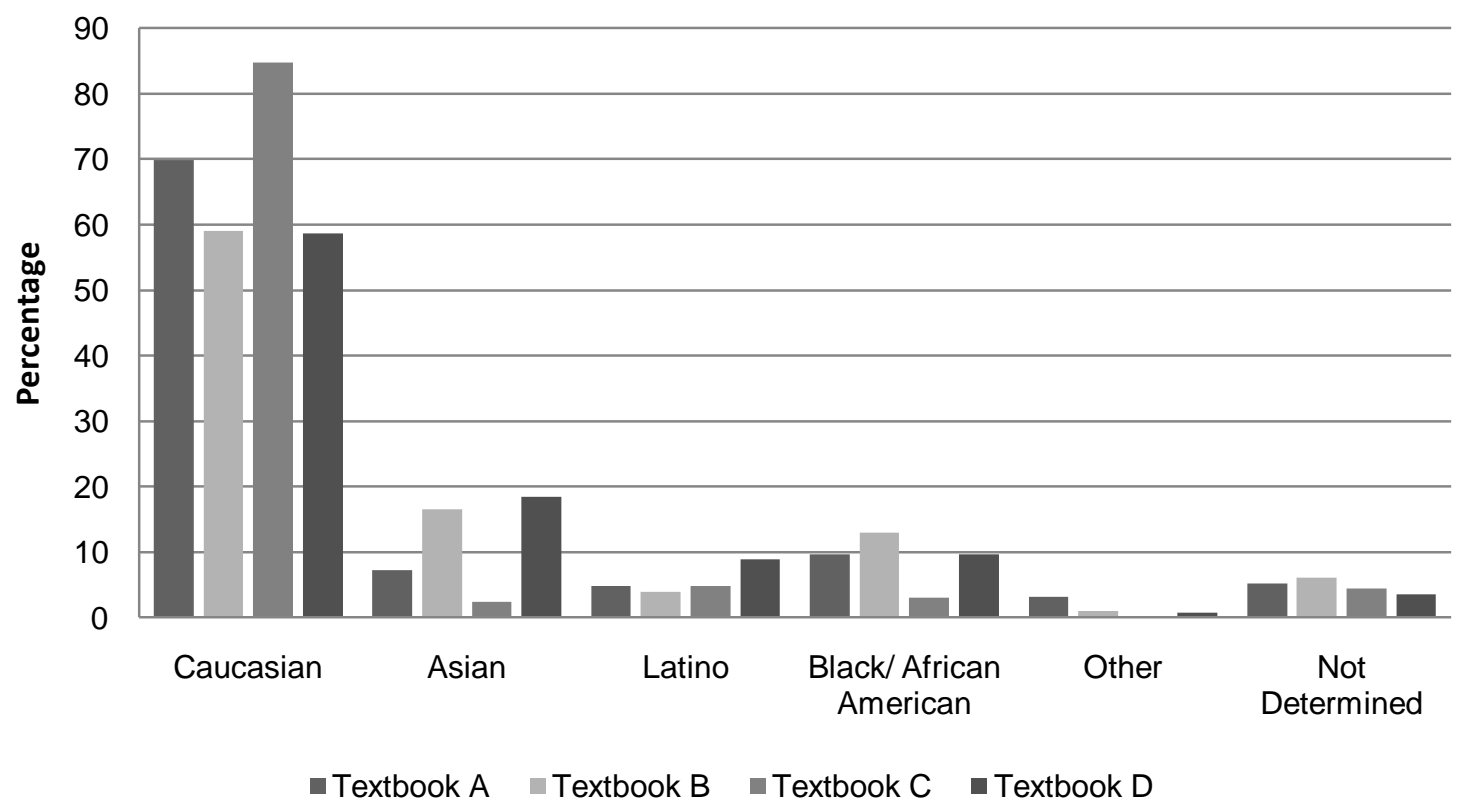

Figure 1. Ethnicity in ELT textbook images

The textbook images include a fairly equal percentage of men and women, which fits with Gray's (2010) observation that more recently produced textbooks show a trend towards 
"feminizing of content" and more egalitarian representation of women. However, only one textbook includes any images of people with disabilities, and no textbooks include any clear images of gays or lesbians, leaving out people with other sexual orientations or gender identities.

\section{Audio Material}

The percentage of audio tracks that include an accent other than standard native speaker accents ranges from $2.80 \%$ to $34.50 \%$. The audio material in the earlier textbooks in particular tend to lump together different nationalities by not including a variety of accents, while the audio tracks in later textbooks distinguish between different varieties of Asian, European, and Middle Eastern accents. Textbook $\mathrm{C}$ and Textbook $\mathrm{D}$ also include a larger variety of native speaker accents.

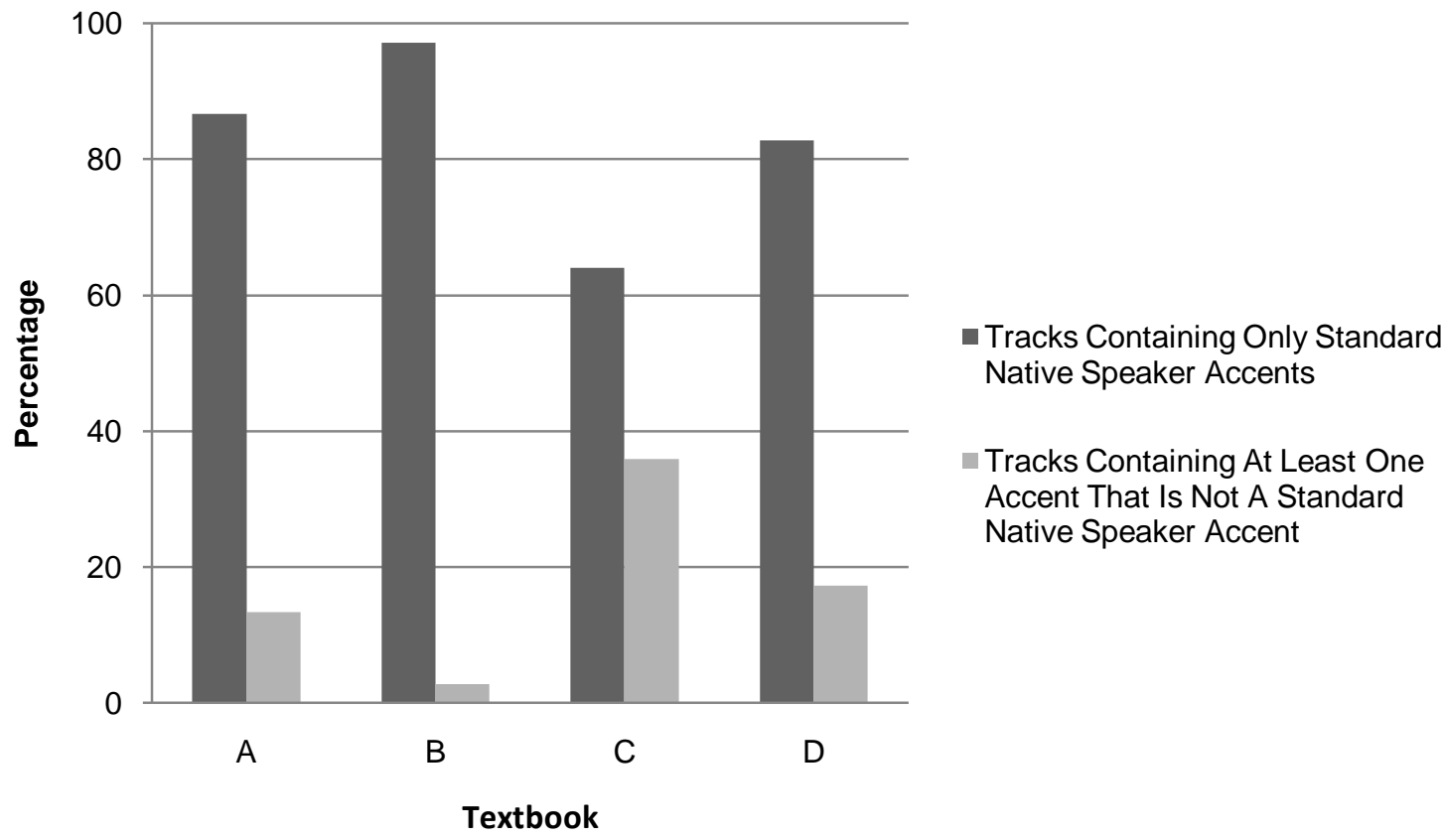

Figure 2. Audio recordings in ELT textbooks

Overall, the audio material in the four textbooks tends to overemphasize the standard native speaker English accent, and international and native speaker accents tend to be mild, standard forms for each country. While two of the textbooks purposely focus on North American accents, they still do not include a variety of regional accents and primarily feature a standard, non-regional dialect. Nonetheless, Textbooks C and D, published in 2008 and 2011 respectively, do include a slightly greater variety of international accents in the audio material than Textbooks A and B, published in 2003 and 2005 respectively. If this trend extends to other recently published English language textbooks, the exposure to different varieties of spoken English could have a positive influence on students.

\section{Underlying Values}

Overall, the textbooks in this study emphasize Western values of individualism, egalitarianism, cosmopolitanism, mobility, affluence, and success. Even if the textbook publishers wanted to purposely include a greater focus on American values and culture in their textbooks, America is a multicultural country and values vary from region to region and person to person, so a more nuanced approach to Western cultural values would be best. 
Some of the texts surveyed openly question some Western values, the drive toward cosmopolitanism, mobility, affluence, and success in particular. For example, Textbook C includes a song which criticizes the modern obsession with money and an article about a woman who lives with no money and few worldly possessions. Textbook A includes a chapter in which a successful but busy lawyer is contrasted with a more content newspaper delivery person. However, the message to students is not always clear. For instance, Textbook B includes both a chapter which discusses the merits of volunteering and another chapter in which success is defined by the material gains of international companies.

Although the textbook authors seem to have made a conscious effort to allow students to express their own values and ideals through debates and discussions, students are often still guided towards a particular perspective. For example, Textbook $C$ features a section comparing stereotypes of male and female activities, such as going shopping, going to the spa, going to the gym, or doing housework. However, this discussion is preceded by a listening activity in which men positively describe a trip to the spa. Thus, while students are free to give their opinion in the gender discussion, the previous activity encourages them to take a stance in favor of gender equality. While exposing students to new ideas from other cultures is beneficial for developing intercultural communicative competence, they should still be given the opportunity to objectively express their own ideas on the topic.

\section{Tourist Viewpoint}

Byram and Esarte-Sarries (1991), Gray (2010), and Shin et al. (2011) found that textbooks often have a tourist viewpoint, meaning that they portray the target culture as exciting, new, and positive from the viewpoint of a tourist visiting the country. In this study, the tourist viewpoint could be seen in the textbooks' emphasis on travel, famous landmarks, and people living abroad. Even when the textbooks include negative information about travel, it is still described as a positive experience. For instance, in both Textbook A and Textbook B, negative feelings of culture shock are easily overcome and portrayed as positive experiences for self development. The hardships people can face while living abroad, prejudices or discrimination against foreigners, and problems that may arise while traveling are never addressed, giving students an overly positive, unrealistic view of other cultures and leaving them unaware and uninformed of deeper issues or problems in other countries.

\section{Cultural Material and Perspective}

In all four textbooks, cultural differences are often presented as a set of objective facts, which can lead students to oversimplify cultural issues and can create a dichotomy between the culture of the target language and students' own culture. For example, Textbook B includes a list of eating customs in six countries, and Textbook $A$ includes a reading passage which outlines rules of etiquette in different parts of the world. These kinds of cultural materials present students with a superficial image of culture as a set of uniform rules without reflecting on underlying cultural values or traditions.

In addition, the textbooks tend to present an unbalanced view of culture which overemphasizes Western cultures. Other than the sections on travel, most of the dialogues and activities in the textbooks take place in English-speaking countries, even when the texts feature non-native English speakers. Impressions on other countries are either given from the viewpoint of a Westerner or from the viewpoint of a foreigner describing English-speaking countries, emphasizing the Western perspective. Again, even if the textbook authors want to focus on Western culture, there should still be a variety of viewpoints represented and a more sophisticated view of culture in general. 


\section{Cultural Activities}

Although all the textbooks include cultural material which can be useful in raising students' cultural awareness, in general, the textbooks do not provide enough in-depth activities to develop students' intercultural communicative competence, which is consistent with the findings of Shin et al. (2011). The most common cultural activities in the textbooks are reading texts, listening to dialogues, and answering short discussion questions in pairs or groups. While these activities are effective at raising students' awareness and cultural knowledge, they do not simulate real intercultural situations.

Byram (2008) believes that intercultural competence involves cultural awareness, knowledge, and skills. This means that students do not just need to develop knowledge and awareness of other cultures, but they also need to develop the skills, attitude, and identity to be able to communicate in intercultural situations. None of the textbooks in this survey provided sufficient opportunities for students to immerse themselves in intercultural activities.

\section{Summary of Results}

The results of this study are summarized in Figure 3 below. Overall, the textbooks were shown to include a limited range of topics and under-represent a number of minority groups and cultures in their images and audio material. Furthermore, the cultural material in the textbooks may represent a limited perspective, give students a superficial view of culture as a set of rules or facts, and prove lacking in overall quality of information.

\begin{tabular}{|l|l|}
\hline Section & Results \\
\hline Topics & $\begin{array}{l}\text { - Lacking in scope } \\
\text { - Avoidance of taboo subjects and issues }\end{array}$ \\
\hline Images & $\begin{array}{l}\text { - Predominantly feature Caucasian characters } \\
\text { - Under-represent minorities, people with disabilities, gay men, and lesbians } \\
\text { - Fairly even percentage of men and women }\end{array}$ \\
\hline $\begin{array}{l}\text { Audio } \\
\text { Material }\end{array}$ & $\begin{array}{l}\text { - Mostly feature standard native speaker accents } \\
\text { - Trend towards including a greater variety of accents from around the world in the } \\
\text { audio material }\end{array}$ \\
\hline Values & $\begin{array}{l}\text { - Few or no tracks with regional American or British accents } \\
\text { - Gobility, affluence, and success }\end{array}$ \\
\hline $\begin{array}{l}\text { Viewpoint / } \\
\text { Perspective }\end{array}$ & $\begin{array}{l}\text { - Overly positive, tourist viewpoint } \\
\text { living or traveling abroad }\end{array}$ \\
\hline Cultural & $\begin{array}{l}\text { - Superficial presentation of culture as a set of facts or rules } \\
\text { - Overemphasis of Western cultures and values }\end{array}$ \\
\hline Material & $\begin{array}{l}\text { - May raise students' cultural awareness or knowledge } \\
\text { - Not effective enough for developing students' intercultural communicative } \\
\text { competence }\end{array}$ \\
\hline Activities
\end{tabular}

Figure 3. Summary of findings 


\section{Implications}

The results of this study suggest that the cultural material in ELT textbooks may be lacking in scope and that the cultural activities included in the textbooks are insufficient for effectively developing students' intercultural communicative competence. The under-representation of different groups of people and cultures, the hidden ideologies and values represented in the texts, the general lack of in-depth cultural materials, and the ineffectiveness of the cultural activities in the textbooks may pose challenges for teachers who are required to use these textbooks for their language classes and may not have the time, knowledge, or skills to create effective supplementary cultural materials for their classes. The findings of this survey raise issues for both textbook publishers and the entire ELT community.

\section{Stereotypes and Under-Representation}

Sleeter and Grant claim that "textbooks continue to legitimize the status of White males" (1991, p. 99). The textbooks in this study certainly present a skewed version of reality, with an overemphasis on Western images, values, and cultures. Caucasians are the most prominent group in all the textbook images, standard native speaker accents are heavily featured in all the audio material, and Western values are present throughout all four textbooks. Even if the goal is to focus on Western culture, these textbooks present students with unrealistic and inaccurate ideas about other cultures and peoples, and gloss over or ignore discrimination through their omission.

Textbooks should include credible and rounded characters from a variety of different backgrounds and cultures rather than continue to focus solely on the experiences of white Westerners. In recent years, publishers have made an attempt to portray women more fairly and positively, avoid gender stereotypes, and include a percentage of female characters and images which reflects the percentage of women in the population worldwide (see Gray, 2002, 2010). It is time that textbook publishers create similar policies for other groups of peoples, including minorities, people with disabilities, and the gay and lesbian community.

\section{Oversimplification of Culture}

The cultural materials included in all four series frequently present simplistic conceptualizations of different cultures. Textbook publishers should include more in-depth cultural materials which include some explanation of cultural practices and traditions and also present several different viewpoints so that students do not assume that culture is a monolithic institution applicable to all members of a society.

\section{Monoperspective, Tourist Viewpoint}

In general, the textbooks represent a Western viewpoint and Western values from the overly positive perspective of a tourist. Since this kind of perspective can give students a false and superficial impression of the target language's culture, textbook publishers need to include more balanced perspectives and viewpoints which include both positive and negative information about other countries and cultures so that students are presented with a genuine view of other cultures. They should also analyze the types of values and perspectives the textbooks portray and avoid including only Western values and perspectives in textbook materials.

\section{Lack of Activities for Developing Students' Intercultural Communicative Competence}

To improve their intercultural communicative competence, students need activities which place them in intercultural situations or enable them to actively participate in a new culture, such as participating in intercultural role-plays, researching other cultures, or actively engaging in another culture's customs and traditions. Textbooks should go beyond merely presenting 
cultural information to including more in-depth cultural activities and discussions that treat culture as a complex, multifaceted set of beliefs, traditions, and customs rather than as a rigid set of rules applicable to entire populations.

\section{Limitations of the Study}

Due to the scope of this study, supplemental material, teacher's editions, workbooks, and websites for each series were not included in the analysis. While the four textbook series were selected to serve as models for ELT textbooks in general and largely corroborate the results of previous studies on curricular and language textbooks, the results of this study are specific to these four textbooks and may not be applicable to other series or other levels of the series selected. More research must be carried out on other series and levels of textbooks and on the supplemental material, teacher's editions, workbooks, and web material accompanying each textbook to determine if the results and trends found in this study are applicable to other series and levels of textbooks.

\section{Conclusion}

This study aimed to expand on previous studies which examined images, stereotypes, representations, ideologies, and culture in language and curricular textbooks by examining four ELT textbooks from a teaching perspective. Overall, the textbooks were shown to underrepresent a number of different peoples, present students with unrealistic and superficial views of other cultures, and fail to provide adequate activities for effectively developing students' intercultural awareness and communication skills.

Teachers should be aware of the values and ideologies included in textbooks and the effect they may have on students' perspectives and personal development. In addition, publishers and authors should be more cautious about representations of other peoples and cultures, hidden values and ideologies within their texts, and the range of perspectives and viewpoints they include in their cultural materials. They should make an effort to include more interactive cultural activities in their textbooks, such as role-plays, cultural research and presentations, active participation in cultural practices and traditions, and opportunities for students to communicate directly with people from other cultural backgrounds. In the meantime, teachers should develop supplemental materials to compensate for the lack of appropriate, in-depth cultural activities include in their textbooks.

As English is considered to be the international language of communication, it is critical that students be given opportunities to develop intercultural awareness and intercultural communicative competence. Thus, it is necessary that publishers make the inclusion of unbiased and effective cultural information and activities in their English language textbooks a priority in order to meet the needs of students in today's global society.

\section{Author Note}

Amanda D. Hilliard, Instructor, American English and Culture Program, Arizona State University, Tempe, Arizona, U.S.A.

Correspondence concerning this article should be addressed to Amanda D. Hilliard, 1021 South Palm Walk, Engineering Center Annex, Room 101, Tempe, Arizona 85281, U.S.A. E-mail: amandahilliard502@gmail.com 


\section{References}

Alptekin, C. (2002). Towards intercultural communicative competence. ELT Journal, 56(1), 5764. http://dx.doi.org/10.1093/elt/56.1.57

Byram, M. (1997). Teaching and assessing intercultural communicative competence. Clevedon, UK: Multilingual Matters.

Byram, M. (2008). From foreign language education to education for intercultural citizenship: Essays and reflections. Clevedon, UK: Multilingual Matters.

Byram, M., \& Esarte-Sarries, V. (1991). Investigating cultural studies in foreign language teaching. Clevedon, UK: Multilingual Matters.

Canagarajah, A. (1999). Resisting linguistic imperialism in English teaching. Oxford, UK: Oxford University Press.

Decapua, A., \& Wintergerst, A. (2004). Crossing cultures in the language classroom. Ann Arbor, MI: Michigan University Press.

Dunnet, S., Dubin, F., \& Lezberg, A. (1986). English language teaching from an intercultural perspective. In J. Valdes (Ed.), Culture bond: Bridging the cultural gap in language teaching (pp. 148-161). Cambridge, UK: Cambridge University Press.

Eriksson, K., \& Aronsson, K. (2005). 'We're really lucky': Co-creating 'us' and the 'Other' in school booktalk. Discourse and Society, 16(5), 719-738. http://dx.doi.org/10.1177/0957926505054943

Forman, R. (2014). How local teachers respond to the culture and language of a global English as a foreign language textbook. Language, Culture, and Curriculum, 271), 72-88. http://dx.doi.org/10.1080/07908318.2013.868473

Gray, J. (2002). The global coursebook in English language teaching. In D. Block \& D. Cameron (Eds.), Globalization and language teaching (pp. 151-167). London, UK: Routledge.

Gray, J. (2010). The construction of English: Culture, consumerism and promotion in the ELT global coursebook. Basingstoke, UK: Palgrave Macmillan.

Gulliver, T. (2010). Immigrant success stories in ESL textbooks. TESOL Quarterly, 44(4), 725745. http://dx.doi.org/10.5054/tq.2010.235994

Heinrich, P. (2005). Language ideology in JFL textbooks. International Journal of the Sociology of Language, 2005(175-176), 213-232. http://dx.doi.org/10.1515/ijsl.2005.2005.175176.213

Kubota, R. (2002). The impact of globalization on language teaching in Japan. In D. Block \& D. Cameron (Eds), Globalization and language teaching (pp. 13-28). London, UK: Routledge.

Lee, K., \& Collins, P. (2010). Construction of gender: A comparison of Australian and Hong Kong English language textbooks. Journal of Gender Studies, 19(2), 121-137. http://dx.doi.org/10.1080/09589231003695856

Naji Meidani, E., \& Pishghadam, R. (2013). Analysis of English language textbooks in the light of English as an international language (EIL): A comparative study. International Journal of Research Studies in Language Learning, 2(2), 83-96.

http://dx.doi.org/10.5861/ijrsll.2012.163

Pennycook, A. (1994). The cultural politics of English as an international language. London, UK: Longman.

Phillipson, R. (1992). Linguistic imperialism. Oxford, UK: Oxford University Press.

Risager, K. (1991). Cultural references in foreign language textbooks: An evaluation of recent tendencies. In D. Butties \& M. Byram (Eds.), Mediating languages and cultures: Towards an intercultural theory of foreign language education (pp. 181-192). Clevedon, UK: Multilingual Matters.

Schnitzer, E. (1995). English as an international language: Implications for interculturalists and language educators. International Journal of Intercultural Relations, 19(2), 227-236. http://dx.doi.org/10.1016/0147-1767(95)00006-W 
Sercu, L. (2010). Assessing intercultural competence: More questions than answers. In A. Paran \& L. Sercu (Eds), Testing the untestable in language education (pp. 17-34). Clevedon, UK: Multilingual Matters.

Sharifian, F. (2013). Globalisation and developing metacultural competence in learning English as an international language. Multilingual Education, 3(1), 1-11. http://dx.doi.org/10.1186/2191-5059-3-7

Shin, J., Eslami, Z., \& Chen, W. (2011). Presentation of local and international culture in current international English-language teaching textbooks. Language, Culture and Curriculum, 24(3), 253-268. http://dx.doi.org/10.1080/07908318.2011.614694

Sleeter, C., \& Grant, C. (1991). Race, class, gender, and disability in current textbooks. In M. Apple \& L. Christian-Smith (Eds.), The politics of the textbook (pp. 78-110). London, UK: Routledge.

Taylor-Mendes, C. (2009). Construction of racial stereotypes in English as a foreign language textbooks: Images as discourse. In R. Kubota \& A. Lin (Eds.), Race, culture, and identities in second language education, (pp. 64-80). London, UK: Routledge.

Yuen, K. (2011). The representation of foreign cultures in English textbooks. ELT Forum 65(4), 458-466. http://dx.doi.org/10.1093/elt/ccq089 
Research

\section{Appendix \\ Framework for Analyzing Cultural Content in English Language Textbooks}

\section{General Information}

Topics (combined from Hall [2002] and Sercu's [2000] framework for cultural content [in Gray, 2010, p. 40])

\begin{tabular}{|c|c|c|c|c|c|}
\hline $\begin{array}{c}\text { Personal Life, } \\
\text { Identity }\end{array}$ & $\begin{array}{c}\text { Family, } \\
\text { Family Life }\end{array}$ & Community & Sports & Health, Welfare & Travel \\
\hline Education & $\begin{array}{c}\text { The Workplace, } \\
\text { Occupations }\end{array}$ & Current Events & Religion & $\begin{array}{c}\text { Arts, } \\
\text { Humanities }\end{array}$ & $\begin{array}{c}\text { Politics, } \\
\text { Charities, World } \\
\text { Organizations }\end{array}$ \\
\hline & $\begin{array}{c}\text { Leisure, } \\
\text { Hobbies }\end{array}$ & Geography & Transportation & $\begin{array}{c}\text { Commerce, } \\
\text { Economy }\end{array}$ & Communication \\
\hline Environment & $\begin{array}{c}\text { Concedia, } \\
\text { Animals }\end{array}$ & Food, Drink & Body, & History & Other \\
\hline Culture & & & Fashion & & \\
\hline
\end{tabular}

Images

\begin{tabular}{|c|l|l|l|l|l|l|l|}
\hline & Caucasian & Asian & Hispanic & $\begin{array}{c}\text { African } \\
\text { American }\end{array}$ & Other & $\begin{array}{c}\text { Not } \\
\text { Determined }\end{array}$ & Total \\
\hline Women & & & & & & & \\
\hline Men & & & & & & & \\
\hline Girls & & & & & & & \\
\hline Boys & & & & & & & \\
\hline
\end{tabular}

Other Comments:

II. Audio

\begin{tabular}{|c|c|c|c|c|}
\hline \multicolumn{5}{|c|}{ Accents Represented } \\
\hline $\begin{array}{c}\text { Standard } \\
\text { North American }\end{array}$ & $\begin{array}{c}\text { Standard } \\
\text { British / Australian }\end{array}$ & $\begin{array}{c}\text { Regional } \\
\text { American Accent }\end{array}$ & $\begin{array}{c}\text { Regional } \\
\text { British / Australian }\end{array}$ & Non-Native Accent \\
\hline & & & & \\
\hline
\end{tabular}

Other Comments: 
III. Cultural Dimensions (from Risager, 1991)

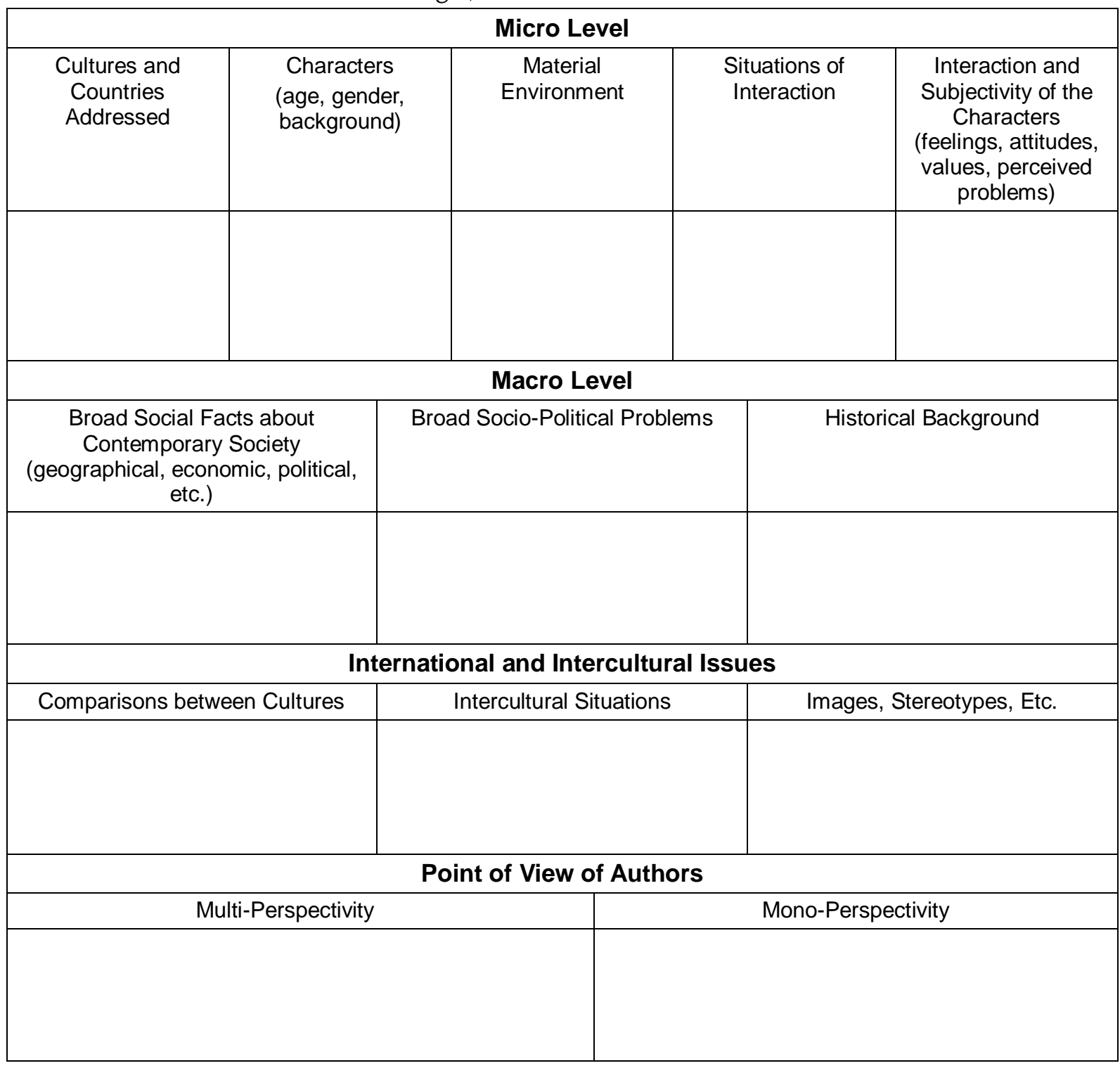

\section{Educational Aspects}

\begin{tabular}{|l|l|l|l|l|l|}
\hline Task Types & Visuals & $\begin{array}{c}\text { Educational } \\
\text { Potential of } \\
\text { Tasks }\end{array}$ & $\begin{array}{c}\text { Main Objective } \\
\text { of Tasks }\end{array}$ & $\begin{array}{c}\text { Level of } \\
\text { Cooperation } \\
\text { Required }\end{array}$ & $\begin{array}{c}\text { Other Task } \\
\text { Characteristics }\end{array}$ \\
\hline & & & & & \\
\hline
\end{tabular}




\section{General Questions}

1. Do the texts / activities address pupils' prior knowledge about the foreign culture?

2. Do the texts / activities address pupils' attitudes to the foreign culture?

3. Do the texts / activities address pupils' own cultural frame of reference?

4. Do the texts / activities focus on aspects of Big C or little c culture?

5. Would the texts / activities be helpful in developing pupils' communicative cultural competence?

6. How could the texts / activities be improved? 